\title{
Cost Stickiness, Corporate Future Losses and Audit Costs
}

\author{
Qiuling Tang \\ School of Management, Jinan University, Guangzhou, China \\ Email: qiu2063264134@163.com
}

How to cite this paper: Tang, Q.L. (2020) Cost Stickiness, Corporate Future Losses and Audit Costs. American Journal of Industrial and Business Management, 10, 110-134. https://doi.org/10.4236/ajibm.2020.101008

Received: December 18, 2019

Accepted: January 6, 2020

Published: January 9, 2020

Copyright $\odot 2020$ by author(s) and Scientific Research Publishing Inc. This work is licensed under the Creative Commons Attribution International License (CC BY 4.0).

http://creativecommons.org/licenses/by/4.0/

\begin{abstract}
Cost stickiness is one of the operating characteristics of enterprises. In the current research literature on the economic consequences of cost stickiness, there is little literature on the relationship between cost stickiness and the possibility of future losses and audit costs. Based on the sample data of Shanghai and Shenzhen A-share listed companies, this paper studies the correlation between cost stickiness and the possibility of future losses, cost stickiness and audit costs. The study found that the greater the cost stickiness of the enterprise, the greater the possibility that the enterprise will suffer losses in the future; and the audit costs will increase as the cost stickiness of the enterprise increases. Further research finds that, compared with non-state-owned enterprises, the cost stickiness of state-owned enterprises has a smaller impact on the possibility of future losses of the enterprise; under different ownership properties, the effect of cost stickiness on audit costs has no significant difference. After the robustness test, the conclusion still holds. This research conclusion helps companies to see more clearly the impact of cost stickiness on business performance, helps CPAs increase their awareness of the risk of cost stickiness, and helps policy regulators realize the importance and necessity of "cost reduction" in "reducing one supplement" and strengthening implementation.
\end{abstract}

\section{Keywords}

Cost Stickiness, Future Losses of Enterprises, Audit Costs, Nature of Equity

\section{Introduction}

With the development of social economy, the competition in the business environment of enterprises is increasing. If an enterprise wants to survive and develop in a fiercely competitive environment, it is inseparable from effective cor- 
porate management. And cost management is one of the top priorities of enterprise management. Cost control and management is the one of the important ways for enterprises to achieve success and long-term development. Compared with other enterprises, excessive costs or excessive rigid costs or excessive idle resource costs make enterprises face higher operating risks and increase the risk of operating failure. Therefore, cost is critical to the business. However, the cost stickiness prevailing in enterprises (Martin et al., 2015; Magheed, 2016; Yusheng Kong, etc., 2007) reflects to some extent that it is difficult for enterprises to reduce costs [1] [2] [3]. The so-called cost stickiness was first discovered by Anderson \& Banker \& Janakiraman (2003) (hereinafter referred to as “ABJ") [4]. They found that the relationship between a company's cost and sales is not symmetrical, which is different from the traditional cost linear assumption. They found that for every $1 \%$ increase in sales, the cost increased by $0.55 \%$; when the sales decreased by $1 \%$, the cost decreased by $0.35 \%$, and based on the concept of price stickiness in economics, they called this phenomenon "cost stickiness". Cost stickiness refers to the fact that when the revenue of an enterprise grows, the increase in cost is higher than when the revenue of a business decreases. Correspondingly, "anti-cost stickiness" means that the degree of cost reduction when sales volume decreases is higher than the degree of cost increase when sales volume increases. Since ABJ (2003), scholars have begun to study the phenomenon of cost stickiness. To some extent, the cost stickiness of an enterprise reflects its operating conditions and operating risks. On the one hand, the cost stickiness of enterprises makes them bear a greater degree of costs when sales decline, increasing the risks of their operations. The existence of rigid costs makes it more likely that companies will make losses (Bo Zhang, 1988) [5]. To some extent, the cost stickiness of an enterprise indicates that the enterprise has a certain degree of non-operating costs or a certain degree of costs that do not create value. Then when the company has cost stickiness, will the cost stickiness of the company increase the possibility of loss in the future? On the other hand, when the company has cost stickiness, it increases the risk of the enterprise to a certain extent (Huobao Xie et al., 2016) [6], which reflects the operating risk of the enterprise to a certain extent. More likely, as one of the company's stakeholders, auditors face greater losses in the face of this situation. Can CPAs identify the potential risk of cost stickiness and charge higher audit fees to cover the cost of this potential risk? It is worth of attention.

The current literature on the economic consequences of cost stickiness is scarce. Studies show that cost stickiness is common in Chinese listed companies (Jian Xu \& Jae Woo Sim, 2017) [7]. Cost stickiness-the change in cost when sales revenue increases is higher than the cost change when sales revenue decreases. The existence of cost stickiness makes it difficult for companies to reduce costs when sales revenue declines, resulting in faster decline in corporate profits and increased business operations risk (Huobao Xie et al., 2016) [6]. In this case, the company is more likely to make losses in the future. Liquan Xing 
and Hanwen Chen (2013) research found that, in conducting audit pricing, CPAs will not only consider the agency issues of enterprises, but also consider their operating risks [8]. Furthermore, when the sales revenue of a company declines, companies with cost stickiness have a greater risk of difficulty in achieving operating performance, and management is more likely to perform earnings management. Therefore, when the company has cost stickiness, the CPA faces greater potential risks due to cost stickiness, and the expected loss is more likely to occur. CPAs are likely to make up for this risk by charging higher audit fees.

At present, most of the existing research literature on cost stickiness is about the existence, causes and factors of cost stickiness. Among them, there are few studies on the economic consequences of cost stickiness, which have only gradually attracted attention in recent years, such as the impact of cost stickiness on company value (Jue Wang \& Mingli Wang, 2017), and the impact on unemployment (Rouxelin et al., 2018) [9] [10]. However, few literatures have studied the impact of cost stickiness on the possibility of future losses and the effect of cost stickiness on audit costs. Therefore, this article will study the impact of cost stickiness on the possibility of future losses and the effect of cost stickiness on audit costs. The specific research questions are as follows: 1) whether cost stickiness has an impact on the possibility of future losses for the enterprise; 2) whether cost stickiness has a significant impact on audit costs; 3) further studies on the cost stickiness of enterprises under different ownership characteristics: the difference in the impact of the possibility of future losses on the enterprise and the difference in the impact of cost stickiness on audit costs under different natures of equity. This paper uses data from all listed companies in China's A-share listed companies from 2007 to 2018. The research conclusions show that: 1) under the control of other variables unchanged, the greater the cost stickiness of the company, the more likely it is that the company will suffer losses in the future; 2) under the control of other variables unchanged, audit pricing will increase as cost stickiness increases; 3 ) further research finds that compared with non-state-owned enterprises, the cost stickiness of state-owned enterprises has smaller impact on the possibility of future losses; there is no significant difference in the impact of corporate cost stickiness on corporate audit costs under different natures of equity.

Studying the relationship between cost stickiness, the possibility of future loss of the company and audit costs, its significance lies in: 1) enriching the influencing factors of audit costs-the existence of enterprise cost stickiness is one of the manifestations of the existence of enterprise risks, and auditors can identify and influence audit costs; 2) Enriched theoretical research on the economic consequences of cost stickiness, considering the economic consequences of cost stickiness from a new dimension-the auditor's dimension of one of the company's stakeholders; which can also studied the impact of the existence of cost stickiness on the company's future operating performance; 3) Studying the impact of cost stickiness on the possibility of future losses and audit costs of the company will 
not only enable auditors to pay more attention to the potential risks of the company in the audit process, but also allow companies aware their own risks and improve their operations. The following research arrangements are as follows: the second part is a literature review; the third part is theoretical analysis and research hypothesis; the fourth part is research design; the fifth part is empirical results and analysis; the sixth part is robustness test; the seventh part is conclusion and inspiration.

\section{Literature Review}

\section{1) Factors of industry losses or company performance}

In the actual operation process of an enterprise, there are many factors that affect its operating performance, and there are also many factors that cause the enterprise to lose money. In general, the factors that affect a company's operating performance or its losses can be broadly divided into two categories: internal factors and external factors. From the perspective of external factors, national policies and economic cycles will affect the business performance of enterprises. From the perspective of internal factors, the company's own management level and operating risks will affect the company's operating performance or the possibility of loss. Yunshi Mao et al. (2001), when analyzing the reasons for the losses of Chinese listed companies, believed that in addition to the lack of technological accumulation and the ability to deal with cross-technology projects, surplus whitewashing, and other factors, the poor management foundation of the enterprises was also an important cause of losses for listed companies [11]. In other words, when the company's own management level is poor, the company is more likely to suffer losses. Similarly, based on a sample of real estate companies, Chuan Zhang et al. (2009) studied the effect of effective internal execution on corporate performance, and found that the effective implementation of internal control can promote corporate performance [12]. The effective implementation of internal control is also one of the manifestations of the company's management level. Pandey et al. (2019) analyzed the impact of debt financing on corporate performance from the perspective of debt financing [13]. His research found that the larger the corporate debt, the greater the negative impact on corporate performance. Furthermore, there are studies from the perspective of corporate costs, which study the impact of costs on corporate performance or corporate losses. Linjie Li et al. (2009) and Kontesa et al. (2018) both found that the cost stickiness of a company can significantly affect its performance [14] [15]. Bo Zhang (1988) analyzed the causes of losses for enterprises, and believed that cost rigidity would cause a large number of enterprises to lose, and that the cost rigidity of different industries had different effects on the possibility of loss [5]. In addition, Meuse et al. (2004) believes that the company's layoffs will affect its long-term performance [16]. When large-scale layoffs occur, the long-term performance of the company is significantly lower than the performance of other companies with fewer layoffs. 


\section{2) Influencing factors of audit costs}

When Simunic (1980) first proposed the audit pricing model, he pointed out that the investment of audit resources and the audit risks that auditors need to bear are important determinants of audit costs [17]. However, Hong Liao and Hua Bai (2001) believed that the audit costs were composed of the cost of the audit product, the expected loss and the normal profit of the firm [18]. Adam et al. (2017) research found that auditors will increase audit fees by increasing audit efforts to deal with audit risks [19]. In addition, they also found that the increase in audit business risk is an important factor affecting future audit costs. Kim et al. (2013) conducted a study of the top three accounting firms in Japan and found that when dealing with clients with high business risks, they mainly used increased audit efforts and audit fees to respond [20]. This shows that the existence of audit risks makes the auditors need to put more audit effort-audit investment to respond, and increases the risks that auditors faced in the future, such as litigation risks (Barron et al., 2001), the risk of reputation damage, the risk of business termination, etc [21]. In theory, audit risk is measured by the risks of material misstatement and inspection, and the risks of material misstatement are affected by the company's control risks and inherent risks. Therefore, auditors charge a risk premium for internal control risks and charge different risk premiums based on the severity of internal control risks (Wei Jiang et al., 2015) [22]. Xiaofeng Quan et al. (2018) believe that companies with senior military experience have lower agency costs, lower inherent risks, and lower audit costs [23]. Similarly, Bailey et al. (2018) research shows that high-quality enterprise risk management systems can reduce audit costs [24]. The results of research by Tianshu Zhang et al. (2013) show that the audit costs of non-state-owned enterprises also increase when the operating risks of enterprises in crisis increase [25]. When the operating risk of an enterprise increases, the risk of bankruptcy and default of the enterprise is greater, and the existing and future risks faced by the auditor are greater. In order to compensate for the hidden costs of such risks, when conducting audit pricing, auditors are also considered the company's operating risk and business risk (Lyon et al., 2005; Houston et al., 1999) [26] [27]. The research by Jamie et al. (1994) also shows that auditors attach equal importance to the operating conditions of enterprises when conducting audit pricing [28]. The study found that auditors will take into account the financial status of the enterprise when considering litigation risks, audit plans and audit costs. This shows that the internal control risks, operating risks, and business risks of the enterprise will also affect audit pricing. Schelleman et al. (2010) argued that auditors consider not only the visible risks but also the potential audit risks when they conduct audit pricing [29].

\section{3) Influencing factors of cost stickiness}

The agency problem is one of the causes of cost stickiness (Wei Jiang and Yuming $\mathrm{Hu}, 2011$ ) [30]. Among them, the motivation of earnings management is one of the factors affecting cost stickiness. There are agency problems between man- 
agers and shareholders. On the one hand, managers are facing pressure from corporate earnings goals. On the other hand, managers' own compensation is often tied to earnings, and even the reputation of managers is affected by earnings. Therefore, managers have surplus management motivations such as avoiding losses and avoiding earnings decline (K. Itay \& W. Dan, 2013) [31]. The motivation of managers to avoid loss of earnings management is likely to reduce the cost stickiness of enterprises. Wuhu Yang (2017) studied the relationship between managers' motivation for earnings management, the nature of equity and cost stickiness [32]. When managers have incentives for earnings management, the cost stickiness of the company is reduced. Similarly, Yongqiang Ma et al. (2013) examined the relationship between the impact of the financial crisis, managers' motivation for surplus, and cost stickiness, and found that managers with a profit motive have reduced their cost stickiness [33]. In other words, the opportunity for managers to maintain profitability reduces the degree of corporate cost stickiness. But the study only shows that under the condition of corporate profit-earning, managers' profit-earning motivation can reduce the existence of corporate cost stickiness. So what impact does cost stickiness have when managers adjust their earnings downwards? Wei Jiang et al. (2015) studied the relationship between managers' accrual earnings management motivation and cost stickiness [34]. Research shows that managers' accrual earnings management behavior will affect the cost stickiness of the company; management's upward adjustment of the accrual surplus will weaken the cost stickiness of the enterprise; management's downward adjustment of the accrual surplus will strengthen the cost stickiness of the enterprise. In addition, adjusting costs is also an important factor that affects the stickiness of costs and expenses. The cost of adjusting resources downwards is greater than the cost of adjusting resources upwards, and management expects-management chooses not based on the expected future operating conditions. Adjustment of resources and agency costs are important factors affecting the stickiness of costs (Pfann A \& Palm C, 1993; Banker et al., 2014; Bing Zhou et al., 2016; Xuegang Cui et al., 2013) [35] [36] [37] [38]. Furthermore, Hongtao Mao et al. (2015) jumped out of the three major factors of adjustment costs, management expectations, and agency costs to study how the social costs borne by enterprises affect the cost stickiness of enterprises [39]. The results of the study show that companies that bear more social costs have higher cost stickiness.

\section{4) Economic consequences of sticky costs}

What are the economic consequences of the widespread existence of cost stickiness on the operation and economic operation of enterprises? The existence of cost stickiness makes enterprises still need to bear larger costs when facing sales revenue decline. Costs cannot be reduced proportionately as sales revenue declines. This makes companies face greater risks. The existence of cost stickiness increases the risk of enterprises (Huobao Xie et al., 2016; Yunjiang Geng et al., 2019) [6] [40]. Similarly, Jue Wang et al. (2017) found that cost 
stickiness significantly increased the risk level of enterprises [9]. When equity concentration is high, cost stickiness has a greater positive impact on enterprises. This shows that the existence of cost stickiness increases the risk level of the enterprise, which reduces the value of the enterprise (Jue Wang and Mingli Wang, 2017) [9]. In addition, the existence of cost stickiness not only affects the company's overall risk level and value, but also affects accounting robustness and the sensitivity of executive compensation performance. Danlu Bu et al. (2016) showed that cost stickiness does confuse the results of accounting robustness [41]. And Huobao Xie and Lili Hui (2017) believe that cost stickiness significantly reduces the sensitivity of executives' pay performance, and this negative relationship is more obvious in private enterprises [42]. The above research shows that cost stickiness is not conducive to the development of enterprises and is not conducive to accounting conservatism. But Anderson M et al. (2007) research believes that cost stickiness actually reflects the management's expectations of future revenue, and the high degree of cost stickiness reflects managers' optimistic expectations for the future [43]. The research results show that during the period of declining income, the cost stickiness of enterprises has a positive relationship with future profits. In other words, the existence of cost stickiness is a reflection of the optimistic expectations of the company's management for the future. The greater the cost stickiness, the more confident the management is in the future sales growth, and the greater the possibility of the company's future profitability. Similarly, Kontesa et al. (2018) used data from Malaysian listed companies to study the impact of cost stickiness on corporate performance, and found that cost stickiness has a significant impact on business performance, but it is not a linear relationship [15]. The above studies are the economic consequences of cost stickiness at the micro level, and Rouxelin et al. (2018) studied the economic consequences of cost stickiness at the macro level [10]. Rouxelin et al. (2018) research found that for each standard deviation of cost stickiness in the most recent quarter, the unemployment rate in the current and future quarters will decrease by $0.23 \%$ to $0.26 \%$ [10]. This shows that the more optimistic executives look at the future, the greater the cost stickiness and the lower the unemployment rate.

\section{5) Summary and evaluation of relevant literature}

a) The cost rigidity of an enterprise, its own operating risk and management level are some of the important factors that affect its performance. Among them, the cost rigidity of listed companies is likely to cause a large number of companies to be loss. To some extent, the cost stickiness reflects the operating status and cost dynamics of the enterprise, and increases the risk of the enterprise to a certain extent and has a significant impact on the performance of the enterprise. So, does the cost stickiness of the enterprise affect the possibility of future losses for the enterprise? This article hopes to study this.

b) Audit inputs, audit risks or audit product costs, expected losses, and the firm's normal profits are important factors affecting audit costs. When the certi- 
fied public accountant collects the audit fee from the audited entity, he will consider not only the direct risk of material misstatement, but also the risk of indirect material misstatement, and charge a certain audit premium for this. To some extent, the cost stickiness reflects the operating conditions and operating risks of the enterprise and increases the risk level of the enterprise. Is the CPA able to identify potential risks and potential expected losses due to cost stickiness and charge an audit premium for this? This article hopes to study this.

\section{Theoretical Analysis and Research Assumptions}

Since ABJ (2003) first introduced the concept of cost stickiness, the research literature on cost stickiness has been endless [4]. However, in the related literature on cost stickiness, there are few literatures that study the impact of cost stickiness on the possibility of future loss and audit costs of the company from the perspective of cost stickiness. Therefore, the main content of this article is to explore: the correlation between cost stickiness and the possibility of future losses; the correlation between cost stickiness and audit costs. Therefore, the theoretical analysis and research hypotheses in this paper mainly start from the causes of corporate losses or performance impacts, audit cost influencing factors, cost stickiness characteristics and economic consequences. While conducting theoretical analysis, this paper proposes research hypotheses in this paper.

1) The relationship between cost stickiness and the possibility of loss in the future

The cause of a company's loss may be caused by internal factors or external environmental factors. Among the internal factors, the company's own internal operating conditions and management level are two of the important reasons affecting the company's losses (Meuse et al., 2004; Yunshi Mao et al., 2001) [11] [16]. In other words, when a company's operating risk is greater or its own management level is poor, the possibility of a loss for the company is greater. In addition, the cost structure and cost management of enterprises are also the important factors that affect the possibility of losses for enterprises (Bo Zhang, 1988) [5]. The cost rigidity of the enterprise will make it more likely that the enterprise will lose money. In other words, the cost of an enterprise, especially the rigid cost, is one of the important factors that affect the loss of an enterprise. Among the many influencing factors on corporate performance, cost stickiness is one of the factors affecting corporate performance (Yunjiang Geng et al., 2019; Kontesa et al., 2018) [15] [40]. This shows that the cost characteristics of an enterprise are one of the factors that affect the performance of the enterprise and one of the factors that affect the possibility of loss for the enterprise. That is, the management level and cost characteristics of an enterprise are some of the important factors that affect the possibility of a loss for the enterprise.

The existence of cost stickiness in enterprises refers to the fact that the increase in costs in the case of increased sales revenue is greater than that in the case of decreased sales revenue (Anderson \& Banker \& Janakiraman, 2003) [4]. 
The greater the cost stickiness, the worse the timely adjustment of corporate costs. In terms of the cause of cost stickiness, in addition to adjusting costs and management expectations, agency costs are also one of the reasons for cost stickiness (Pfann A \& Palm C, 1993; Banker et al., 2014; Xuegang Cui et al. 2013) [35] [36] [38]. If the cost stickiness of an enterprise is caused by agency costs, the existence of cost stickiness to a certain extent indicates that there are certain problems in the internal governance of the enterprise. At the same time, the existence of cost stickiness in enterprises will increase the risk level of enterprises to some extent (Huobao Xie et al., 2016; Yunjiang Geng et al., 2019) and reduce the value of enterprises (Jue Wang \& Mingli Wang, 2017) [6] [9] [40].

First, when a company has cost stickiness, it reflects the cost characteristics of the company to a certain extent. The greater the cost stickiness of a company, it means that it is difficult for the company's cost to adjust to the environment in a short time. To a certain extent, the company bears part of the costs that do not match the value. Compared with enterprises that do not have cost stickiness or lower cost stickiness, companies with higher cost stickiness are more likely to be loss.

Furthermore, when a company has cost stickiness, it is likely to be caused by the agency cost of the company. At this time, the existence of corporate cost stickiness reflects the agency problem of the enterprise to a certain extent. The greater the cost stickiness, the greater the agency costs that the company may have. At this time, it reflects the more serious agency problems of the enterprise. This is likely to indicate that there are certain problems with corporate internal governance. Poor internal management of enterprises will make them more likely to suffer losses (Yunshi Mao et al., 2001) [11]. Therefore, the existence of cost stickiness, from the perspective of its agency costs, will increase the possibility of future losses for the company.

Finally, the existence of corporate cost stickiness, to some extent, reflects its operating conditions and operating risks, increasing the level of corporate risk (Yunjiang Geng et al., 2019) [40]. The greater the cost stickiness of an enterprise, the greater the level of risk it faces. When an enterprise's risk increases, it will affect the company's financing costs and other aspects, thereby further increasing its operating risk and making it more likely for the company to lose money.

Therefore, based on the above analysis, this article believes that cost stickiness has a significant positive relationship with the possibility of future losses. Put forward hypothesis 1:

$\mathrm{H} 1$ : With other conditions unchanged, cost stickiness is positively related to the possibility of future losses for the company.

\section{2) The relationship between cost stickiness and audit costs}

The audit investment and the audit risk undertaken by the CPA in the audit process are important factors affecting audit costs (Simunic, 1980) [17]. At the same time, Hong Liao and Hua Bai (2001) found that the cost of audit products, expected losses and the firm's normal profit are important factors affecting audit 
costs [18]. Audit product costs are mainly affected by audit inputs, including human and material inputs; expected losses are caused by direct or indirect audit risks. Xiaoxia Liu et al. (2019), when studying the impact of negative news in the media, found that CPAs will charge an audit premium for the direct or indirect material misstatement risks reflected in such negative reports [44]. In other words, in the audit process, the CPA will pay attention to the direct or indirect potential risks that affect audit risks.

Cost stickiness refers to the fact that in the course of business operation, when the sales revenue increases, the cost increase is greater than the sales reduction. This cost stickiness phenomenon is not only caused by adjustment costs and management's expected effects, but also by agency costs (Xuegang Cui et al., 2013) [38]. Therefore, on the one hand, when a company has cost stickiness, it fundamentally increases the risk of the company (Huobao Xie et al., 2016) [6]. Compared with other enterprises, companies with cost stickiness are more likely to experience operating conditions such as a decline in earnings, a surplus loss, or operating failure. On the other hand, if cost stickiness is caused by the existence of agency costs, the existence of cost stickiness at this time is likely to indicate that there are more serious agency problems within the enterprise. This article analyzes cost stickiness and auditing costs from two aspects of operational risk and agency issues.

First of all, from the perspective of operation, the cost stickiness of an enterprise reflects to a certain extent the operating conditions of the enterprise and the operating risks faced by the enterprise. Cost stickiness is one of the comprehensive indicators of internal and external risks (Huobao Xie and Lili Hui, 2017) [42]. Tianshu Zhang and Jun Huang (2013) found that when the financial crisis occurred in 2008, the company's operating risk was increased; after controlling other variables that affect audit costs, it was found that as the company's operating risk increases, CPAs will charge higher Audit costs [25]. In other words, the operating risks of an enterprise will be of concern to certified public accountants. When a company's operating risk is high, on the one hand, it is more likely that the company will have a loss or a decline in earnings. At this time, the company is more likely to have earnings management. The possibility of business failure in the future will also be greater, making the company's continued operation under certain doubts. The cost stickiness of the enterprise increases the potential risks assumed by the CPA and increases the possibility of expected losses. As the supervision becomes more stringent, the audit failures and litigation risks that CPAs need to bear are also increasing. Once the audit fails, the economic losses and reputation losses will be greater. In order to avoid the risk of audit failure and subsequent litigation, the risk of CPAs will continuously increase their awareness of legal risks, maintain a high degree of professional skepticism, and increase audit investment (Xuehua Zhang and Xiaolin Chen, 2015) [45]. The CPA will charge a certain risk premium in order to make up for the risks brought by these potential risks and the degree of increased audit invest- 
ment in response to these risks.

Secondly, the existence of agency costs is also one of the important influencing factors on the cost stickiness of enterprises. Therefore, when a company has high cost stickiness, it is likely to indicate that the company has a serious agency problem. Chunyan Zhu et al. (2017) found that when there is no separation of the two powers, the audit fee decreases and then increases with the increase in the proportion of major shareholders [46]. This shows that the higher the agency cost, the higher the audit fee charged by the CPA. Liquan Xing and Hanwen Chen (2013) believe that the product market competition intensity has a significant negative correlation with audit costs, and the agency cost effect is dominant [8]. In other words, when a certified public accountant faces the agency cost of an enterprise, it will increase its audit expenses to cope with the risks brought by the agency cost and the increase in audit investment. Based on the above analysis, this article believes that the greater the cost stickiness of an enterprise, the greater the audit cost of the enterprise. Put forward hypothesis 2:

$\mathrm{H} 2$ : With other conditions unchanged, cost stickiness is positively related to audit costs.

\section{Research Design}

\section{1) Model Design}

In order to test Hypothesis 1 , and to test whether cost stickiness affects the possibility of future losses, this paper uses the following model to test:

$$
\text { later_loss } s_{i, t+1}=\beta 0+\beta 1 * \mathrm{dcscost}_{i, t}+\operatorname{controls}_{i, t}+e_{i, t} \text { model }
$$

Among them, the explained variable later_loss ${ }_{i, t+1}$ is a measure of the possibility of future losses for the company. This article adopts whether the enterprise $(t$ $+1)$ period is the profit before interest and $\operatorname{tax}\left(\mathrm{EBIT}_{i, t+1} / \mathrm{asset}_{i, t+1}\right.$, that is, the profit before interest and tax in $t+1$ period $/ t+1$ period total assets) to measure whether a loss occurs. Later_loss ${ }_{i, t+1}$ : if the company's profit margin before interest and tax for $t+1$ period is negative, later_loss $s_{i, t+1}$ is set to 1 , otherwise it is 0 .

The measurement of the explanatory variable dcscost $_{i, t}$ this paper refers to the method of Anderson and Lanen [47], and uses the following Formulas (1) and (2) to calculate the cost stickiness.

$$
\begin{aligned}
& \text { cost_ratio }=\left(\operatorname{cost}_{i, j} \operatorname{rev}_{i, j}\right)-\left(\operatorname{cost}_{i, i-1} / \operatorname{rev}_{i, i-1}\right) \quad \text { Formula (1) } \\
& \text { dcscost }_{i, i}=\text { cost_ratio } \times \text { Dcost } \times \text { Drev Formula (2) }
\end{aligned}
$$

In Formula (2), Dcost and Drev are dummy variables. When cost_ratio is greater than 0 , Dcost takes the value 1, otherwise it is 0 . When $\left(\operatorname{rev}_{i, i} / \operatorname{rev}_{i, i-1}\right)<1$, Drev takes the value 1, Otherwise 0 .

Based on Hypothesis 1, $\beta 1>0$ is expected. Control variables controls include: enterprise size, asset-liability ratio-lev, business complexity-cfratio, growth rate of the company, whether loss occurred in year $t$, ownership of major shareholders, ownership of senior executives-stock_e, two-in-one-same, Independent director ratio-EID, etc. Finally, control the year and industry. 
In order to test Hypothesis 2, to avoid a large magnitude difference from the independent variable, this paper uses the logarithm value of the audit fee for period $t$ of the enterprise as the explained variable in this article, which represents the size of the audit fee; it is denoted as ln_auditfee ${ }_{i, r^{*}}$ The explanatory variable is dcscost $_{i, i}$ Build the following models:

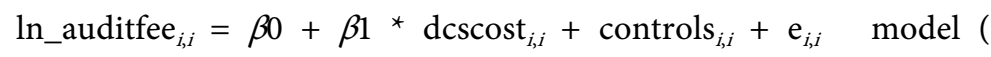

The control variables include: size (similarly, in order to avoid the problem that the level of the total assets is too large compared to other variables, the natural logarithm is used to measure the size of the assets ), asset-liability ratio-lev, business complexity-cfratio, growth rate of the company, whether or not a loss occurs, ownership of major shareholders, ownership of senior shareholders, stock_e for senior executives, same two-in-one same, proportion of independent directors EID, whether it is big4 of the Big Four accounting firms, audittype of audit opinion, etc.

The detailed definitions of the main variables in this paper are shown in $\mathrm{Ta}$ ble 1 .

Table 1. Definition of main variables.

\begin{tabular}{|c|c|}
\hline Variable & Definition \\
\hline \multicolumn{2}{|l|}{ Explained variable } \\
\hline $\begin{array}{l}\text { possibility of future losses for the } \\
\text { company-later_loss } s_{i, i+1}\end{array}$ & $\begin{array}{l}\text { If the company's profit margin before interest and tax for } t+1 \\
\text { period is less than } 0 \text {, it is } 1 \text {, otherwise it is } 0 \text {; }\end{array}$ \\
\hline audit fee-ln_auditfee ${ }_{i, i}$ & The logarithm of audit fees for period t of the enterprise; \\
\hline \multicolumn{2}{|l|}{ Explanatory variables } \\
\hline Cost stickiness-dcscost ${ }_{i, i}$ & Calculated using the formulas (1) and (2) above; \\
\hline \multicolumn{2}{|l|}{ Control variable } \\
\hline Enterprise size-size & Logarithm of total assets of the enterprise; \\
\hline Assets and liabilities-lev & Corporate liabilities/total corporate assets; \\
\hline Business complexity-cfratio & (Receivable + inventory)/total assets; \\
\hline growth rate-growth & $\begin{array}{l}\text { (Net profit for the current year-Net profit for the previous } \\
\text { year)/Net profit for the previous year; }\end{array}$ \\
\hline a loss occurred in $\mathrm{t}$ years-loss & 1 if the enterprise incurred a loss in year $t$; otherwise, 0 ; \\
\hline $\begin{array}{l}\text { Shareholding ratio of major } \\
\text { shareholders-ownership }\end{array}$ & $\begin{array}{l}\text { Number of shares held by the largest shareholder/total capital } \\
\text { of the company; }\end{array}$ \\
\hline Executive Shareholding_-stock_e & Number of shares held by executives/total number of shares; \\
\hline same & $\begin{array}{l}\text { Same is } 1 \text { if the general manager and the chairman are the } \\
\text { same person, otherwise } 0 \text {; }\end{array}$ \\
\hline Independent director ratio-EID & Number of independent directors/boards; \\
\hline big4 & $\begin{array}{l}\text { If the accounting firm is the Big Four, the value of big } 4 \text { is } 1 \text {, } \\
\text { otherwise it is } 0 \text {; }\end{array}$ \\
\hline audit opinion-audittype & $\begin{array}{l}\text { At period } t \text {, if the audit opinion is non-standard, the value is } 1 \text {, } \\
\text { otherwise it is } 0 \text {; }\end{array}$ \\
\hline
\end{tabular}




\section{2) Selection of samples}

The sample data is mainly from the Guotai'an database. The data range for the sample selection is all A-share listed companies in China listed companies from 2007 to 2018. Aiming at the sample data in this article, the data was processed using stata11.0 software.

In order to avoid the impact of some missing or inappropriate data, the following data screening process has been performed: 1) delete data from the financial industry; 2) delete data from net assets and total assets less than or equal to 0 ; 3 ) delete business data of revenue and operating cost less than or equal to zero. At the same time, in order to avoid the influence of extreme values, $1 \%$ Winsor processing was performed on the continuous variables, and the final data sample was obtained. In this paper, the clustering robust standard error method is used for control.

\section{Empirical Results and Analysis}

\section{1) Descriptive statistics}

Table 2 is the result of descriptive statistics of the main variables.

From the descriptive statistics in Table 2, it can be known that the average value of cost stickiness dcscost is 0.013 , the maximum value is 0.416 , and the standard deviation is 0.055 . The interpreted variable later_loss, whose average value is 0.089 , indicates that in the sample studied, the company will account for about $9 \%$ of losses in the next year. The audit cost of the explanatory variable ln_auditfee has an average value of 13.64 and a standard deviation of 0.72 . The size of the asset has a mean value of 21.94, a minimum value of 19.3, a maximum value of 25.93, and a standard deviation of 1.302 . The average growth rate of profit growth $(-0.409)$ indicates that the companies in the sample have a negative growth from the average level. The average value of loss is 0.081 , which is similar to the average of later_loss. The two jobs are one-same mean value is 0.257 , indicating that about $25.7 \%$ of the companies in the sample have the phenomenon of two jobs being one. The average value of independent directors-EID is 0.372 . On average, the company's independent directors have reached one-third of the regulatory requirements.

\section{2) Correlation analysis}

Table 3 is the correlation analysis results of related variables.

Table 3 is the result of correlation analysis between variables. Among them, there is a significant positive correlation between later_loss and dcscost. The correlation between later_loss and dcscost is 0.052 , and is significantly positive at a significance level of $5 \%$, which is consistent with hypothesis 1 . However, since this is a simple correlation analysis between univariate variables, further testing is needed. But there is a significant negative correlation between $l n \_$auditfee and dcscost. Similarly, because correlation analysis is a correlation analysis between univariate variables, you need to look at the relationship between the two while considering other variables. 
Table 2. Descriptive statistics of the main variables.

\begin{tabular}{ccccccc}
\hline Variable & Mean & Median & Std. & Min. & Max. & $N$ \\
\hline later_loss & 0.089 & 0.000 & 0.284 & 0.000 & 1.000 & 25,230 \\
In_auditfee & 13.640 & 13.530 & 0.720 & 12.300 & 16.280 & 27,448 \\
dcscost & 0.013 & 0.000 & 0.055 & 0.000 & 0.416 & 25,327 \\
size & 21.940 & 21.780 & 1.302 & 19.300 & 25.930 & 28,825 \\
lev & 0.435 & 0.430 & 0.213 & 0.048 & 0.905 & 28,825 \\
cfratio & 0.267 & 0.245 & 0.170 & 0.006 & 0.756 & 28,613 \\
growth & -0.409 & 0.043 & 4.041 & -26.130 & 13.200 & 25,368 \\
loss & 0.081 & 0.000 & 0.272 & 0.000 & 1.000 & 28,825 \\
ownership & 0.353 & 0.334 & 0.151 & 0.0878 & 0.757 & 28,820 \\
stock_e & 0.069 & 0.0002 & 0.140 & 0.000 & 0.615 & 27,575 \\
same & 0.257 & 0.000 & 0.437 & 0.000 & 1.000 & 28,381 \\
EID & 0.372 & 0.333 & 0.055 & 0.000 & 0.800 & 28,697 \\
big4 & 0.0544 & 0.000 & 0.227 & 0.000 & 1.000 & 28,825 \\
audittype & 0.0341 & 0.000 & 0.181 & 0.000 & 1.000 & 28,715 \\
\hline
\end{tabular}

Table 3. Correlation analysis between variables.

\begin{tabular}{|c|c|c|c|c|c|c|c|}
\hline Variable & later_loss & In_auditfee & $d c s c o s t$ & size & lev & cfratio & growth \\
\hline later_loss & 1.000 & & & & & & \\
\hline In_auditfee & $-0.016^{\star *}$ & 1 & & & & & \\
\hline$d \operatorname{cscost}$ & $0.052^{\star \star *}$ & $-0.025^{\star \star *}$ & 1 & & & & \\
\hline size & $-0.063^{* * *}$ & $0.754^{\star * *}$ & $-0.059^{\star * *}$ & 1 & & & \\
\hline lev & $0.055^{\star * *}$ & $0.303^{* * *}$ & -0.003 & $0.446^{* * *}$ & 1 & & \\
\hline cfratio & $-0.029^{\star * *}$ & $-0.026^{* * *}$ & -0.006 & -0.002 & $0.255^{\star * *}$ & 1 & \\
\hline growth & $-0.130^{* * *}$ & $0.017^{\star * *}$ & -0.006 & $0.057^{\star \star \star}$ & $-0.093^{\star * *}$ & $0.022^{\star * *}$ & 1 \\
\hline loss & $0.148^{\star * *}$ & $-0.020^{\star * *}$ & $0.027^{\star \star \star}$ & $-0.088^{\star * *}$ & $0.126^{\star * *}$ & $-0.031^{\star * *}$ & $-0.480^{\star \star *}$ \\
\hline ownership & $-0.086^{* * *}$ & $0.131^{\star * *}$ & $-0.026^{\star * *}$ & $0.211^{\star \star \star}$ & $0.049^{\star \star \star}$ & -0.002 & $0.044^{* * *}$ \\
\hline stock_e & $-0.046^{* * *}$ & $-0.166^{* * *}$ & $-0.045^{\star \star *}$ & $-0.257^{\star * *}$ & $-0.295^{\star * *}$ & $0.035^{\star * *}$ & $0.033^{* * *}$ \\
\hline same & -0.00700 & $-0.091^{* * *}$ & -0.00700 & $-0.171^{\star * *}$ & $-0.162^{\star * *}$ & $0.031^{\star * *}$ & $0.011^{\star}$ \\
\hline EID & -0.00001 & $0.059^{* * *}$ & $0.018^{\star * *}$ & $0.025^{\star * *}$ & $-0.018^{\star * *}$ & $0.029^{* * *}$ & $-0.021^{\star * *}$ \\
\hline big4 & $-0.027^{\star * *}$ & $0.453^{* * *}$ & -0.004 & $0.350^{* * *}$ & $0.099^{* * *}$ & $-0.062^{\star * *}$ & $0.011^{\star}$ \\
\hline audittype & $0.158^{\star * *}$ & $-0.018^{\star \star \star}$ & $0.070^{\star * *}$ & $-0.104^{\star * *}$ & $0.129^{* * *}$ & $-0.050^{\star * *}$ & $-0.126^{\star * *}$ \\
\hline Variable & loss & ownership & stock_e & same & EID & big4 & audittype \\
\hline loss & 1 & & & & & & \\
\hline ownership & $-0.090^{\star * *}$ & 1 & & & & & \\
\hline stock_e & $-0.063^{\star * *}$ & $-0.024^{* * *}$ & 1 & & & & \\
\hline same & $-0.013^{\star *}$ & $-0.045^{\star * *}$ & $0.482^{\star * *}$ & 1 & & & \\
\hline$E I D$ & $0.018^{\star * *}$ & $0.039^{* * *}$ & $0.095^{\star * *}$ & $0.105^{\star * *}$ & 1 & & \\
\hline big4 & $-0.031^{\star * *}$ & $0.139^{\star * *}$ & $-0.089^{\star \star *}$ & $-0.070^{\star * *}$ & $0.033^{\star * *}$ & 1 & \\
\hline audittype & $0.238^{\star * *}$ & $-0.096^{\star * *}$ & $-0.055^{\star \star \star}$ & -0.005 & 0.002 & $-0.030^{\star * *}$ & 1 \\
\hline
\end{tabular}


The correlation results between other control variables show that the largest correlation coefficient is the correlation coefficient between growth and loss $(-0.48)$. This shows that there is no serious multicollinearity problem between the variables.

\section{3) Analysis of empirical results}

Table 4 is the regression results of the correlation between inspection cost stickiness and the possibility of future losses for the enterprise, and the correlation between inspection cost stickiness and audit costs.

Panel A in Table 4 is the regression result of the correlation between cost stickiness and the possibility of future losses for the company. This paper uses a panel logistic regression model for multiple regression analysis. Column (1) in Panel A is the cross-section regression; Column (2) is the panel regression result. Column (1) and Column (2) regression results show that under the control of other variables, the explanatory variable cost stickiness dcscost is significantly positive at a significance level of $1 \%$, and the coefficients are 2.053 and 1.875, respectively. This shows that there is a significant positive correlation between corporate cost stickiness and the possibility of future losses. The greater the cost stickiness of an enterprise, the greater the possibility that the enterprise will suffer losses in the future. This article assumes 1 is true. From an economic point of view, subject to Column (2), for each standard deviation of cost stickiness, the probability of future losses for the company will change by $10.313 \%(1.875$ * $0.055)$; the probability of future losses for the company will change by 1.159 $(0.10313 / 0.089)$. When the cost stickiness of an enterprise is greater, the higher the risk level of the enterprise, the greater the possibility that the enterprise will suffer losses in the future. This research conclusion shows that the cost characteristics of enterprises is one of the important reasons that affect the loss of enterprises. Enterprises should pay attention to their operating costs and avoid bearing excessive non-operating costs or non-value costs.

Panel B in Table 4 is the regression result obtained by testing the correlation between cost stickiness and audit costs. Column (1) in Panel B is the result of multiple regression of mixed regression; Column (2) is the result of fixed-effect regression that controls the time variable. The results of Column (1) and Column (2) both show that under the control of other variables, the cost stickiness dcscost is significantly positive at a significance level of $5 \%$, with coefficients of 0.137 and 0.078 , respectively. This shows that the cost stickiness of an enterprise has a significant positive correlation with audit costs; the greater the cost stickiness of an enterprise, the greater the audit cost. Assumption 2 holds. From an economic perspective, based on the fixed-effect regression results, audit costs will increase by $0.429 \%(0.078 * 0.055)$ for each standard deviation of cost stickiness; audit costs will increase by $0.0314 \%(0.00429 / 13.64)$. In other words, the CPA will charge higher audit fees for the cost stickiness of the enterprise. The greater the cost stickiness of the enterprise, the greater the audit costs. 
Table 4. Multiple regression results.

\begin{tabular}{|c|c|c|c|c|c|}
\hline \multirow{2}{*}{\multicolumn{3}{|c|}{$\begin{array}{l}\text { Panel A: results of the correlation between cost } \\
\text { stickiness and the possibility of future losses } \\
\text { Explained variable-later_loss }\end{array}$}} & \multicolumn{3}{|c|}{$\begin{array}{l}\text { Panel B: results of the correlation } \\
\text { between cost stickiness and audit costs }\end{array}$} \\
\hline & & & & Explained va & -In_auditfee \\
\hline \multirow[t]{2}{*}{ Variable } & $\begin{array}{c}\text { Cross-section } \\
\text { regression }\end{array}$ & $\begin{array}{c}\text { Panel } \\
\text { regression }\end{array}$ & Variable & $\begin{array}{c}\text { Mixed } \\
\text { regression }\end{array}$ & $\begin{array}{l}\text { Fixed } \\
\text { effect }\end{array}$ \\
\hline & (1) & (2) & & (1) & (2) \\
\hline \multirow[t]{2}{*}{$d \operatorname{cscost}$} & $2.053^{\star * *}$ & $1.875^{\star * *}$ & dcscost & $0.137^{\star *}$ & $0.078^{\star *}$ \\
\hline & (5.47) & (4.39) & & $(2.29)$ & $(2.34)$ \\
\hline \multirow[t]{2}{*}{ size } & $-0.296^{\star * *}$ & $-0.256^{\star \star *}$ & size & $0.366^{* * *}$ & $0.339^{\star * *}$ \\
\hline & $(-11.76)$ & $(-7.90)$ & & $(46.74)$ & (33.15) \\
\hline \multirow[t]{2}{*}{ lev } & $1.432^{* * *}$ & $1.445^{\star * *}$ & lev & 0.035 & 0.014 \\
\hline & $(10.16)$ & $(8.19)$ & & $(0.96)$ & $(0.42)$ \\
\hline \multirow[t]{2}{*}{ cfratio } & $-0.839^{* * *}$ & $-0.911^{* * *}$ & cfratio & 0.057 & -0.026 \\
\hline & $(-5.07)$ & $(-4.34)$ & & (1.39) & $(-0.62)$ \\
\hline \multirow[t]{2}{*}{ growth } & $-0.046^{* * *}$ & $-0.051^{* * *}$ & growth & 0.001 & -0.000 \\
\hline & $(-8.31)$ & $(-8.30)$ & & $(0.71)$ & $(-0.25)$ \\
\hline \multirow[t]{2}{*}{ loss } & $0.590^{* * *}$ & -0.166 & loss & $0.068^{* * *}$ & $0.021^{\star * *}$ \\
\hline & $(7.01)$ & $(-1.64)$ & & $(5.05)$ & $(2.70)$ \\
\hline \multirow[t]{2}{*}{ ownership } & $-1.075^{\star * *}$ & $-1.471^{* * *}$ & ownership & $-0.100^{* *}$ & 0.068 \\
\hline & $(-5.81)$ & $(-6.11)$ & & $(-2.20)$ & $(1.08)$ \\
\hline \multirow[t]{2}{*}{ stock_e } & $-0.816^{* * *}$ & $-1.011^{\star * *}$ & stock_e & $-0.118^{* * *}$ & $-0.084^{*}$ \\
\hline & $(-3.28)$ & $(-3.36)$ & & $(-2.86)$ & $(-1.71)$ \\
\hline \multirow[t]{2}{*}{ same } & 0.037 & 0.063 & same & $0.025^{\star}$ & 0.008 \\
\hline & $(0.58)$ & $(0.81)$ & & $(1.96)$ & $(0.80)$ \\
\hline \multirow[t]{6}{*}{$E I D$} & 0.310 & -0.044 & $E I D$ & $0.190^{*}$ & -0.036 \\
\hline & $(0.66)$ & $(-0.08)$ & & $(1.83)$ & $(-0.51)$ \\
\hline & & & big4 & $0.729^{\star * \star}$ & $0.265^{\star * *}$ \\
\hline & & & & (18.19) & $(5.46)$ \\
\hline & & & audittype & $0.183^{* * *}$ & $0.094^{\star * *}$ \\
\hline & & & & $(8.02)$ & $(5.70)$ \\
\hline \multirow[t]{2}{*}{ _cons } & $3.266^{\star * *}$ & $2.315^{\star * \star}$ & _cons & $5.075^{\star * *}$ & $5.888^{\star * *}$ \\
\hline & $(5.64)$ & $(3.12)$ & & $(29.26)$ & $(26.40)$ \\
\hline Ind./ Year & Yes & Yes & Ind./ Year & Yes & Yes \\
\hline$N$ & 20,400 & 20,400 & $N$ & 22,868 & 22,887 \\
\hline $\operatorname{adj}-R^{2}$ & - & - & $\operatorname{adj}-R^{2}$ & 0.672 & 0.645 \\
\hline$F$ & - & - & $F$ & $429.2^{* * *}$ & $405.77^{\star * *}$ \\
\hline
\end{tabular}

Note: 1) the year and industry are controlled; 2 ) the $t$ value in parentheses; ${ }^{*}, * * * * *$ indicate that they are significant at the statistical levels of $10 \%, 5 \%$, and $1 \%$. 


\section{4) Further research and analysis}

Considering the differences in the business objectives and business methods of enterprises in China's capital market under different natures of equity. Compared with non-state-owned enterprises, state-owned enterprises have stronger financing and anti-risk capabilities. Therefore, under the same circumstances, if there is cost stickiness, is it more likely that state-owned enterprises will lose money than non-state-owned enterprises. Similarly, whether there are differences in the CPA's treatment of related matters of different equity companies. This article starts with the correlation between cost stickiness and the possibility of future losses, cost stickiness and auditing costs, and studies whether there is a difference in this impact relationship under different natures of equity.

This article describes the nature of equity as soe, which is defined as: if the enterprise is a state-owned enterprise, the value of soe is 1 , otherwise it is 0 .

This article will use crossover terms to test the cost stickiness of different equity properties and the possibility of future losses for the company; crossover terms and grouping methods will be used to test the difference in the impact of cost stickiness on audit costs under different stock right properties.

The test results are shown in Table 5.

Table 5. Differences in the impact of cost stickiness on the possibility of future losses and audit costs for different types of equity.

\begin{tabular}{|c|c|c|}
\hline \multicolumn{3}{|c|}{$\begin{array}{l}\text { Panel } A \text { : The test of cross-correlation differences in the } \\
\text { nature of different stock rights using crossover terms }\end{array}$} \\
\hline \multirow{2}{*}{ Variable } & ExplainedVariable-later loss & Explained variable-In_auditfee \\
\hline & (1) & (2) \\
\hline dcscost & $2.414^{\star * *}$ & $0.198^{\star * *}$ \\
\hline soe & 0.090 & $-0.048^{* * *}$ \\
\hline$d c s c o s t^{\star}$ soe & $-2.161^{\star \star}$ & -0.109 \\
\hline Others Var. & Yes & Yes \\
\hline Ind./ Year & Yes & Yes \\
\hline$N$ & 19100 & 21695 \\
\hline $\operatorname{adj}-R^{2}$ & - & 0.667 \\
\hline \multicolumn{3}{|c|}{$\begin{array}{l}\text { Panel B: Tests on the differences of related relationships } \\
\text { under different ownership properties by grouping }\end{array}$} \\
\hline \multirow{3}{*}{ Variable } & Explained & - In_auditfee \\
\hline & state-owned enterprises & state-owned enterprises \\
\hline & (5) & \\
\hline dcs_cost & 0.045 & $0.082^{*}$ \\
\hline Difference & \multicolumn{2}{|c|}{0.037} \\
\hline Others Var. & Yes & Yes \\
\hline Ind./ Year & Yes & Yes \\
\hline$N$ & 8036 & 13,768 \\
\hline $\operatorname{adj}-R^{2}$ & 0.651 & 0.600 \\
\hline
\end{tabular}

Note: 1$)$ the year and industry are controlled; 2 ) the $t$ value in parentheses; ${ }^{*},{ }^{*},{ }^{* *}$ indicate that they are significant at the statistical levels of $10 \%, 5 \%$, and $1 \%$. 
Panel $\mathrm{A}$ in Table 5 is the result of multiple regression using the crossover term. Column (1) in Panel A is the test result of the difference in the impact of cost stickiness on the possibility of future losses of the company under different ownership properties. From the results of Panel A (1), it can be seen that under the control of other variables, the crossover term dcscost ${ }^{\star}$ soe is significantly negative at a significance level of $5 \%$. This shows that, compared with state-owned enterprises, the cost stickiness of non-state-owned enterprises is more likely to increase the possibility of future losses. Column (2) in Panel A is the test result of the difference in the impact of cost stickiness on audit fees under different ownership properties. Under the control of other variables, the crossover term dcscost ${ }^{*}$ soe is not significantly different from 0 at a significance level of $10 \%$. This shows that compared with state-owned enterprises, the cost stickiness of non-state-owned enterprises has no significant difference in the impact of audit costs.

It can be seen that for enterprises, compared with non-state-owned enterprises, state-owned enterprises are better able to cope with the risk of future losses caused by cost stickiness; however, CPAs charge audit fees for the risks brought by cost stickiness, not treated differently because of the different nature of equity.

\section{Robustness Test}

In order to increase the reliability of the hypothesis test results in this paper, the following robustness tests were performed. Except for the logistic regression model, the following robustness tests use a fixed effect model under the control of time.

\section{1) Add control variables}

In order to reduce the endogenous problems caused by the omission of variables, this article considers adding control variables in the robustness test: 1) whether the senior management of the company has changed during $t$ period, and is recorded as change_zd (definition: if the company's $t$ period, the chairman or the general manager changes, change_zd is set to 1 , otherwise 0 ); 2) The earnings management motive at the t-period of the enterprise is used as the control variable and recorded as MP (definition: if the roe is in the $(-0.02,0.02)$ range at the $t$-period of the enterprise in this case, the value of MP is 1 , otherwise it is 0 ). The reason to consider joining change_zd is that when the executives change, the enterprise risks are greater and the possibility of loss is higher. The CPA will also charge higher audit fees for this. MP refers to the motivation of corporate earnings management. When a company has an earnings management motivation, it will make the company less or more likely to suffer losses. The existence of earnings management motivation will increase the audit risk of the certified public accountant. Auditors will charge a higher audit premium to deal with it.

The test results are shown in Table 6 (1) and (2). The regression results obtained are consistent with the main regression. 
Table 6. Regression results of the robustness test.

\begin{tabular}{|c|c|c|c|c|c|}
\hline Variable & $\begin{array}{c}\text { Explained variable } \\
\text {-later_loss }\end{array}$ & $\begin{array}{l}\text { Explained variable } \\
\text {-In_auditfee }\end{array}$ & Variable & $\begin{array}{c}\text { Explained variable } \\
\text {-later_loss }\end{array}$ & $\begin{array}{c}\text { Explained variable } \\
\text {-In_auditfee }\end{array}$ \\
\hline & (1) & (2) & & (3) & (4) \\
\hline$d \operatorname{cscost}$ & $1.865^{* * *}$ & $0.078^{\star *}$ & cha_dcscost & $1.878^{\star * *}$ & $0.071^{\star *}$ \\
\hline change_zd & $0.180^{* * *}$ & $0.010^{\star *}$ & & & \\
\hline$M P$ & $1.756^{\star * *}$ & -0.006 & & & \\
\hline others Var. & Yes & Yes & others Var. & Yes & Yes \\
\hline Ind./ Year & Yes & Yes & Ind./ Year & Yes & Yes \\
\hline$N$ & 20,400 & 22,887 & $N$ & 20,400 & 22,887 \\
\hline $\operatorname{adj}-R^{2}$ & - & 0.645 & $\operatorname{adj}-R^{2}$ & - & 0.645 \\
\hline \multirow[t]{2}{*}{ Variable } & $\begin{array}{c}\text { Explained variable } \\
\text {-later_roa }\end{array}$ & $\begin{array}{l}\text { Explained variable } \\
\text {-cha_Inauditfee }\end{array}$ & Variable & $\begin{array}{l}\text { Explained variable } \\
\text {-later_sdroa }\end{array}$ & $\begin{array}{l}\text { Explained variable } \\
\text { - cha_Inauditfee }\end{array}$ \\
\hline & (5) & (6) & & (7) & (8) \\
\hline \multirow[t]{2}{*}{$d \operatorname{dccost}$} & $-0.020^{\star \star}$ & $0.083^{\star *}$ & dcscost & $0.023^{* * *}$ & \\
\hline & & & cha_dcscost & & $0.073^{\star}$ \\
\hline others Var. & Yes & Yes & others Var. & Yes & Yes \\
\hline Ind./ Year & Yes & Yes & Ind./ Year & Yes & Yes \\
\hline$N$ & 20,417 & 22,887 & $N$ & 20,459 & 22,887 \\
\hline $\operatorname{adj}-R^{2}$ & 0.008 & 0.782 & $\operatorname{adj}-R^{2}$ & 0.128 & 0.782 \\
\hline
\end{tabular}

Note: 1$)$ the year and industry are controlled; 2 ) the $t$ value in parentheses; ${ }^{*},{ }^{*},{ }^{* *}$ indicate that they are significant at the statistical levels of $10 \%, 5 \%$, and $1 \%$.

\section{2) Take cost stickiness difference as explanatory variable}

This paper uses the cost stickiness difference to measure the explanatory variable in the transformation of the explanatory variable method, that is, the difference between the cost stickiness of the enterprise itself and the average cost stickiness of the same industry in the same year as the explanatory variable is recorded as cha_dcscost.

The regression results are shown in Table 6 (3) and (4). The conclusions obtained are consistent with the regression results. The test results obtained are consistent with the main regression.

3) Take the profit rate before interest and tax of the enterprise $t+1$ period and the difference between audit fees as the explanatory variables

In this paper, in this robustness test, the profit margin before interest and tax of the company $t+1$ period will be used to replace the later_loss in the model; the difference in audit costs will be used to replace the explained variable-audit cost in the original regression model. The specific measurement method is as follows:

Enterprise's $t+1$ period EBIT margin: Enterprise's $t+1$ period EBIT/enterprise's $t+1$ period total assets; recorded as later_roa. If the cost stickiness is greater, the more likely the company will lose money in the future. This article hopes that dcscost has a significant negative correlation with later_roa. 
Audit cost difference: the audit cost of an enterprise-the average audit cost of an enterprise in the same industry and year, recorded as cha_lnauditfee. That is, the difference between the company's own audit costs and the average of the company's audit costs in the same industry in the same year is used as a replacement of the audit costs of the explanatory variables of the original regression model to perform the robustness test.

The results obtained by the regression are shown in Columns (5) and (6) in Table 6. The regression results in Column (5) show that under the control of other variables, dcscost is significantly negative at a significance level of $10 \%$, indicating that the greater the cost stickiness, the smaller the company's future EBIT margin, and the more likely it is to lose money. The conclusions reached are consistent with the main regression. Similarly, the conclusions from the regression results of Column (6) are consistent with the main regression.

\section{4) Robustness test in other ways}

Robustness test of the impact of cost stickiness on the possibility of future losses:

The volatility of roa during the period of the enterprise $(t, t+2)$ is used to measure the stability of the company's surplus, and it is recorded as later_sdroa. If the cost stickiness of an enterprise is greater, the greater the later_sdroa, it indicates that the existence of the cost stickiness of the enterprise affects the stability of performance, and the possibility of loss in the later period is greater.

The test results are shown in Column (7) in Table 6. Column (7) regression results show that, under the condition of controlling other variables, dcscost is significantly positive at a significance level of $1 \%$. This shows that the greater the cost stickiness of the enterprise, the greater the volatility of the company's future profits, and the greater the possibility of loss. This is consistent with the conclusions of the main regression.

Robustness test of the impact of cost stickiness on audit fees:

Using the calculated audit fee difference-cha_lnauditfee as the explanatory variable and cost sticky difference-cha_dcscost as the explanatory variable, the influence of cost stickiness on auditing costs is examined. This test method can reduce the endogenous problems caused by reverse causality to a certain extent.

The test results are shown in Column (8) in Table 6. The conclusions of the regression results are consistent with the main regression.

\section{5) Summary}

The above robustness tests all show that the conclusion of the main regression is valid. The conclusions obtained in this paper are relatively stable.

\section{Conclusions and Inspiration}

With the development of social economy, the operating environment enterprises faced is becoming more and more complicated, and competition is becoming more and more intense. Cost management and cost control have become an important part of the survival and development of enterprises in such an envi- 
ronment. The existence of corporate cost stickiness increases the risk level of the enterprise to a certain extent and affects the business risk of the enterprise. What kind of economic consequences the cost stickiness of the enterprise brings is worthy of attention. From the perspective of the economic consequences of cost stickiness, this paper explores whether the existence of cost stickiness affects the possibility of future losses and the impact of cost stickiness on audit costs. The study found that the greater the cost stickiness of an enterprise, the greater the possibility that the company will suffer losses in the future; the greater the cost stickiness of an enterprise, the greater the audit costs. After the robustness test, the conclusion still holds. This shows that the cost stickiness of the company will indeed increase the business risk of the company in the future, making it more likely for the company to make losses. At the same time, the CPA can identify the potential risks brought by cost stickiness and bring about the cost stickiness. An audit premium is charged for potential risks or increased expected losses, resulting in higher audit costs. In further research, the differences in the impact of cost stickiness on the possibility of future losses of enterprises under different natures of equity and the differences in the impact of cost stickiness on audit costs under different natures of equity are discussed. The study found that, compared with non-state-owned enterprises, the cost stickiness of state-owned enterprises has a smaller effect on the possibility of future losses for the company; and the impact of cost stickiness on audit costs has no significant difference under different ownership characteristics.

From the perspective of cost stickiness, this article explores the economic consequences of cost stickiness. Its research conclusions allow companies to better understand the impact of their own cost stickiness on their business processes, which in turn helps companies strengthen their own cost control and avoid the negative impact of cost stickiness. For CPAs, allow CPAs to deepen their understanding of the potential risks caused by cost stickiness and strengthen their professional skepticism, so as to reduce audit risks caused by increasing audit investment or adjusting audit procedures; for policy supervisors, the conclusion of the study indicates that certain costs of the enterprise will affect the long-term development of the enterprise. The importance of the proposed "cost reduction" plan can be seen. Policy regulators should strengthen their implementation to help some companies with excessive cost rigidities reduce their costs, to promote the development of enterprises, industries and the economy.

This article for the first time studies the impact of cost stickiness on future losses and audit costs from the perspective of cost stickiness. This research enriches the existing relevant literature research, and also helps the practice community to further understand the negative impact of cost stickiness on the future operation of the enterprise. And this research also helps auditors to clarify the potential risks brought by cost stickiness, which affects audit decisions. The research shows to a certain extent the significance of the relevant departments' active promotion of related policies on industry cost control. 
However, the research in this paper still has deficiencies and needs further research in the future. First, this article does not consider the impact of cost stickiness on the possibility of future losses and audit costs of different companies by industry. Secondly, this article has not yet explored the impact of cost stickiness on more aspects of business operations. The above-mentioned shortcomings deserve further study in the future.

\section{Conflicts of Interest}

The author declares no conflicts of interest regarding the publication of this paper.

\section{References}

[1] Bugeja, M., Lu, M. and Shan, Y. (2015) Cost Stickiness in Australia: Characteristics and Determinants. Australian Accounting Review, 25, 248-261. https://doi.org/10.1111/auar.12066

[2] Magheed, A. (2016) The Determines of the Sticky Cost Behavior in the Jordanian Industrial Companies Listed in Amman Stock Market. Journal of Accounting, 23, 64-82.

[3] Kong, Y.S., Zhu, N.P. and Kong, Q.G. (2007) Research on Cost Stickiness: Empirical Evidence from Chinese Listed Companies. Accounting Research, No. 11, 58-65. http://kns.cnki.net//KXReader/Detail?TIMESTAMP=637129671584493750\&DBCO $\underline{\mathrm{DE}}=\mathrm{CJFQ} \& \mathrm{TABLEName}=\mathrm{CJFD} 2007 \&$ FileName $=$ KJYJ200711010\&RESULT $=1 \& S \mathrm{SI}$ GN=63i18XvMTZTKPX\%2fbxKYch8G5nqY\%3d

[4] Janakiraman, A.B. (2003) Are Selling, General, and Administrative Costs "Sticky". Journal of Accounting Research, 41, 47-63. https://doi.org/10.1111/1475-679X.00095

[5] Zhang, B. (1988) Inducement of Long-Term Enterprise Loss: Stock Rigidity. Management World, No. 4, 74-85.

https://kns.cnki.net/KCMS/detail/detail.aspx?dbcode=CJFQ\&dbname=CJFD8589\&f ile-

$\underline{\text { name }=\text { GLSJ198804007\&uid }=\text { WEEvREcwSlJHSldRa1FhcTdWa2FjcW9wSytha1JOY }}$ XpJZzRJQnBTZDRPcz0=\$9A4hF_YAuvQ5obgVAqNKPCYcEjKensW4IQMovwHt wkF4VYPoHbKxJw!!\&v=MjY1NjllUnBGeTNtVUx2UElpSFlaTEt4RnRuTXE0OUZ ZNFI4ZVgxTHV4WVM3RGgxVDNxVHJXTTFGckNVUkxPZVo=

[6] Xie, H.B. and Hui, L.L. (2016) Investment Efficiency, Cost Stickiness and Enterprise Risk-Based on the Perspective of Macroeconomic Uncertainty. Journal of Nanjing Institute of Auditing, No. 2, 3-11.

[7] Xu, J. and Sim, J.W. (2017) Are Costs Really Sticky and Biased? Evidence from Manufacturing Listed Companies in China. Applied Economics, 49, 5601-5613. https://doi.org/10.1080/00036846.2017.1316823

[8] Xing, L.Q. and Chen, H.W. (2013) Product Market Competition, Competitive Position and Audit Fees-Based on Dual Considerations of Agency Costs and Operating Risks. Audit Research, No. 3, 50-58.

https://kns.cnki.net/KCMS/detail/detail.aspx?dbcode=CJFQ\&dbname=CJFD2013\&f ile-

$\underline{\text { name }}=$ SJYZ201303011\&uid=WEEvREcwSIJHSldRa1FhcTdWa2FjcW9wSytha1JOY XpJZzRJQnBTZDRPcz0=\$9A4hF_YAuvQ5obgVAqNKPCYcEjKensW4IQMovwHt wkF4VYPoHbKxJw!!\&v=MjY2NzZyV00xRnJDVVJMT2VaZVJwRnkzbVZiN05Oa WZTZExHNEg5TE1ySTlFWllSOGVYMUx1eFlTN0RoMVQzcVQ= 
[9] Wang, J. and Wang, M.L. (2017) Cost Stickiness, Enterprise Growth and Enterprise Value. Finance and Accounting Newsletter, No. 24, 35-37.

[10] Rouxelin, F., Wongsunwai, W. and Yehuda, N. (2018) Aggregate Cost Stickiness in GAAP Financial Statements and Future Unemployment Rate. The Accounting Reviews, 93, 299-325. https://doi.org/10.2308/accr-51939

[11] Mao, Y.S., Jiang, D.F. and Cheng, Y.P. (2001) Study on the Loss and Reconstruction of Chinese Listed Companies. Management World, No. 5, 145-151.

[12] Zhang, C., Shen, H.B. and Gao, X.Z. (2009) Effectiveness of Internal Control, Auditor Evaluation and Enterprise Performance. Audit Research, No. 6, 79-86.

[13] Pandey, K.D. and Sahu, T.N. (2019) Debt Financing, Agency Cost and Firm Performance: Evidence from India. Vision, 23, 267-274. https://doi.org/10.1177/0972262919859203

[14] Li, L.J. and Zhang, X.H. (2019) Cost Stickiness, Organizational Redundancy and Company Performance. Finance and Accounting Newsletter, No. 15, 59-62.

[15] Maria, K. and Rayenda Khresna, B. (2018) Cost Stickiness Effect on Firm's Performance: Insights from Malaysia. Asia-Pacific Management Accounting Journal, 13, 1-14.

[16] Meuse, K.P., Bergmann, T.J., Vanderheiden, P.A. and Roraff, C.E. (2004) New Evidence Regarding Organizational Downsizing and a Firm's Financial Performance: A Long-Term Analysis. Journal of Managerial Issues, No. 2, 155-177.

[17] Simunic, D.A. (1980) The Pricing of Audit Services: Theory and Evidence. Journal of Accounting Research, 18, 161-190. https://doi.org/10.2307/2490397

[18] Liao, H. and Bai, H. (2001) Research on Audit Fees of American Certified Public Accountants. Chinese Certified Public Accountants, No. 8, 62-64.

[19] Greiner, A., Kohlbeck, M.J. and Smith, T.J. (2017) The Relationship between Aggressive Real Earnings Management and Current and Future Audit Fees. Journal of Practice and Theory, 36, 85-107.

https://doi.org/10.2308/ajpt-51516

[20] Kim, H. and Fukukawa, H. (2013) Japan's Big 3 Firms' Response to Clients' Business Risk: Greater Audit Effort or Higher Audit Fees. International Journal of Auditing, 17, 190-212. https://doi.org/10.1111/j.1099-1123.2012.00464.x

[21] Orie, B., Jamie, P. and Stice, J.D. (2001) Misstatement Direction, Litigation Risk, and Planned Audit Investment. Journal of Accounting Research, 39, 449-462. https://doi.org/10.1111/1475-679X.00022

[22] Jiang, W. and Son, M. (2015) Do Audit Fees Reflect Risk Premiums for Control Risk. Journal of Accounting, Auditing and Finance, 30, 318-340. https://doi.org/10.1177/0148558X14560896

[23] Quan, X.F., Xu, X.M. and Cai, W.H. (2018) Does the Experience of Executives in the Military Affect Audit Costs. Audit Research, No. 2, 80-86.

http://kns.cnki.net//KXReader/Detail?TIMESTAMP=637129673039337500\&DBCO $\mathrm{DE}=\mathrm{CJFQ} \& \mathrm{TABLEName}=\mathrm{CJFDLAST} 2018 \&$ FileName$=$ SJYZ201802013\&RESULT $=$ $1 \&$ SIGN=62U3k05B8EkKv1Vz9BIiTP9EfZY\%3d

[24] Bailey, C., Collins, D.L. and Abbott, L.J. (2018) The Impact of Enterprise Risk Management on the Audit Process: Evidence from Audit Fees and Audit Delay. $A$ Journal of Practice and Theory, 37, 25-46. https://doi.org/10.2308/ajpt-51900

[25] Zhang, T.S. and Huang, J. (2013) Research on Audit Fee Risk Premium in Financial Crisis. Accounting Research, No. 5, 81-87. http://kns.cnki.net//KXReader/Detail?TIMESTAMP=637129673655743750\&DBCO $\underline{\mathrm{DE}}=\mathrm{CJFQ} \& \mathrm{TABLEName}=\mathrm{CJFD} 2013 \&$ FileName $=$ KJYJ201305013\&RESULT $=1 \&$ SI GN=HE59My0uxMedHzNzf7HdnEFEoa0\%3d 
[26] Lyon, J.D. and Maher, M.W. (2005) The Importance of Business Risk in Setting Audit Fees: Evidence from Cases of Client Misconduct. Journal of Accounting Research, 43, 133-151. https://doi.org/10.1111/j.1475-679x.2005.00165.x

[27] Houston, R.W., Peters, M.F. and Pratt, J.H. (1999) The Audit Risk Model, Business Risk and Audit-Planning Decisions. The Accounting Review, 74, 281-298. https://doi.org/10.2308/accr.1999.74.3.281

[28] Pratt, J. and Stice, J.D. (1994) The Effects of Client Characteristics on Auditor Litigation Risk Judgments, Required Audit Evidence, and Recommended Audit Fees. The Accounting Review, 69, 639-656.

[29] Schelleman, C. and Robert Knechel, W. (2010) Short-Term Accruals and the Pricing and Production of Audit Services. AUDITING. A Journal of Practice and Theory, 29, 221-250. https://doi.org/10.2308/aud.2010.29.1.221

[30] Jiang, W. and Hu, Y.M. (2011) Corporate Cost Expense Stickiness: Literature Review and Prospect. Accounting Research, No. 9, 74-79.

[31] Itay, K. and Dan, W. (2013) Do Earnings Targets and Managerial Incentives Affect Sticky Costs. Journal of Accounting Research, 51, 201-224. https://doi.org/10.1111/j.1475-679X.2012.00471.x

[32] Yang, W.H. (2017) Motivation of Managers' Earnings Management, the Nature of Stock Ownership and Corporate Cost Stickiness. Finance and Accounting Newsletter, No. 24, 80-84.

[33] Ma, Y.Q. and Zhang, Z.N. (2013) Research on Impact of Financial Crisis, Managers' Surplus Motivation and Stickiness of Enterprise Costs and Costs. Nankai Management Review, No. 6, 70-80.

[34] Jiang, W., Hu, Y.M. and Zeng, Y.Q. (2015) Financing Constraints and Corporate Cost Stickiness: Based on Empirical Evidence from China's Industrial Enterprises. Financial Research, No. 10, 133-147.

http://kns.cnki.net//KXReader/Detail?TIMESTAMP=637129674280118750\&DBCO DE $=$ CJFQ\&TABLEName $=$ CJFDLAST2016\&FileName $=J R Y J 201510009 \&$ RESULT $=$ $1 \&$ SIGN=mzE6ji7bVA9ym\%2fHN\%2bpTDkSOpErA\%3d

[35] Pfann, A. and Palm, C. (1993) Asymmetric Adjustment in Non-Linear Labour Demand Models for the Netherlands and U.K. Manufacturing Sectors. The Review of Economic Studies, 60, 397-412. https://doi.org/10.2307/2298064

[36] Banker, D., Byzalov, D., Ciftci, M. and Mashruwala, R. (2014) The Moderating Effect of Prior Sales Changes on Asymmetric Cost Behavior. Journal of Management Accounting Research, 26, 221-243. https://doi.org/10.2308/jmar-50726

[37] Zhou, B., Zhong, T.Y., Xu, H. and Ren, Z. (2016) Enterprise Strategy, Manager Expectations and Cost Stickiness. Accounting Research, No. 7, 58-65.

[38] Cui, X.G. and Xu, J.L. (2013) Overseas Listing, Binding Mechanism and Stickiness of Corporate Expenses. Accounting Research, No. 12, 33-40.

[39] Mao, H.T., Li, Z.Y. and Cheng, J. (2015) Can Non-Economic Drivers Lead to Sticky Cost Behavior of Enterprises. Nankai Management Review, 18, 136-145.

[40] Geng, Y.J. and Wang, L.Q. (2019) Cost Stickiness, Internal Control Quality and Enterprise Risk. Accounting Research, No. 5, 75-81. http://kns.cnki.net//KXReader/Detail?TIMESTAMP=637129674960900000\&DBCO $\underline{\mathrm{DE}}=\mathrm{CJFQ} \& \mathrm{TABLEName}=\mathrm{CJFDTEMP} \&$ FileName $=$ KJYJ201905010\&RESULT $=1 \& \mathrm{~S}$ IGN=Bey\%2fbNwaoG\%2bczWi6zNhpDj1XPiU\%3d

[41] Bu, D.L., Cai, C.H. and Banker, R. (2016) Cost Stickiness and Measurement of Earnings Robustness. Accounting Research, No. 1, 31-37. 
[42] Xie, H.B. and Hui, L.L. (2017) Cost Stickiness, Corporate Governance and Sensitivity of Executive Compensation Performance-Empirical Evidence Based on Corporate Risk Perspective. Management Review, 29, 110-125.

[43] Anderson, M., Banker, R., Huang, R. and Janakiraman, S. (2007) Cost Behavior and Fundamental Analysis of SG \& A Costs. Journal of Accounting, Auditing \& Finance, 22, 1-28. https://doi.org/10.1177/0148558X0702200103

[44] Liu, X.X., Li, M.H. and Sun, L. (2017) Negative Media Reports, Audit Pricing and Audit Delays. Accounting Research, No. 4, 88-96.

https://kns.cnki.net/KCMS/detail/detail.aspx?dbcode=CJFQ\&dbname=CJFDLAST2 017\&filename=KJYJ201704013\&uid=WEEvREcwSlJHSldRa1FhcTdWa2FjcW9wSyt ha1JOYXpJZzRJQnBTZDRPcz0=\$9A4hF_YAuvQ5obgVAqNKPCYcEjKensW4IQ MovwHtwkF4VYPoHbKxJw!!\&v=MTU0NjJDVVJMT2VaZVJwRnkzblVML0xMa WZTWkxHNEg5Yk1xNDlFWjRSOGVYMUx1eFITN0RoMVQzcVRyV00xRnI=

[45] Zhang, X.H. and Chen, X.L. (2015) Special General Partnership, Potential Litigation Risks of Clients and Earnings Management. Contemporary Finance and Economics, No. 7, 108-117.

[46] Zhu, C.Y., Wu, L.N. and Tian, L.H. (2017) The Impact of Agency Costs and Flexible Information Disclosure on Audit Fees. Accounting Research, No. 7, 89-95.

[47] Anderson, S.W. and Lanen, W.N. (2007) Understanding Cost Management: What Can We Learn from the Sticky Cost. SSRN 975135.

https://doi.org/10.2139/ssrn.975135 